\title{
Proteomic profiling of the interface between the stomach wall and the pancreas in dystrophinopathy
}

\author{
Paul Dowling (1,2), Stephen Gargan (1,2), Margit Zweyer (3), Hemmen Sabir (3), \\ Michael Henry (4), Paula Meleady (4), Dieter Swandulla (5), Kay Ohlendieck $(1,2)$
}

(1) Department of Biology, Maynooth University, National University of Ireland, Maynooth, Co. Kildare, Ireland; (2) Kathleen Lonsdale Institute for Human Health Research, Maynooth University, Maynooth, Co. Kildare, Ireland, (3) Department of Neonatology and Paediatric Intensive Care, Children's Hospital, University of Bonn, Bonn, Germany; (4) National Institute for Cellular Biotechnology, Dublin City University, Dublin 9, Ireland; (5) Institute of Physiology II, University of Bonn, Bonn, Germany.

This article is distributed under the terms of the Creative Commons Attribution Noncommercial License (CC BY-NC 4.0) which permits any noncommercial use, distribution, and reproduction in any medium, provided the original author(s) and source are credited.

\begin{abstract}
The neuromuscular disorder Duchenne muscular dystrophy is a multi-systemic disease that is caused by a primary abnormality in the X-chromosomal Dmd gene. Although progressive skeletal muscle wasting and cardio-respiratory complications are the most serious symptoms that are directly linked to the almost complete loss of the membrane cytoskeletal protein dystrophin, dystrophic patients also suffer from gastrointestinal dysfunction. In order to determine whether proteome-wide changes potentially occur in the gastrointestinal system due to dystrophin deficiency, total tissue extracts from the interface between the stomach wall and the pancreas of the $m d x-4 c v$ model of dystrophinopathy were analysed by mass spectrometry. Following the proteomic establishment of both smooth muscle markers of the gastrointestinal system and key enzymes of the pancreas, core members of the dystrophin-glycoprotein complex, including dystrophin, dystroglycans, sarcoglycans, dystrobrevins and syntrophins were identified in this tissue preparation. Comparative proteomics revealed a drastic reduction in dystrophin, sarcoglycan, dystroglycan, laminin, titin and filamin suggesting loss of cytoskeletal integrity in $m d x-4 c v$ smooth muscles. A concomitant increase in various mitochondrial enzymes is indicative of metabolic disturbances. These findings agree with abnormal gastrointestinal function in dystrophinopathy.
\end{abstract}

Key Words: Duchenne muscular dystrophy; mdx-4cv; pancreas; proteomics; stomach.

Eur J Transl Myol 31 (1): 9627, 2021 doi: 10.4081/ejtm.2021.9627

Duchenne muscular dystrophy is the most common neuromuscular disorder of early childhood and almost exclusively affects boys due to its $\mathrm{X}$-chromosomal pattern of inheritance. The disease is characterized by highly progressive skeletal muscle degeneration in association with reactive myonecrosis and late-onset cardio-respiratory deficiencies. ${ }^{1}$ Genetic abnormalities in one of the largest genes in the human genome, the 79exon spanning Dmd gene, trigger the almost complete loss of its full-length protein product, the Dp427-M isoform of dystrophin. ${ }^{2}$ However, since several different promoters are involved in the tissue-specific production of a variety of dystrophin isoforms that range in molecular mass from $45 \mathrm{kDa}$ to $427 \mathrm{kDa}$, the effects of mutations in the Dmd gene cause intricate changes in the expression of various dystrophin proteoforms. ${ }^{3}$
This genetic complexity might explain, at least partially, body-wide complications in dystrophinopathies that usually require multi-disciplinary care of Duchenne patients. ${ }^{4}$ Besides the striking dystrophic phenotype of muscle-associated necrosis, fibrosis and inflammation that directly impairs muscle strength, cardiac output and respiratory efficiency, ${ }^{1}$ additional symptoms include scoliosis, endocrine disturbances, reduced bone mineralization, impaired energy metabolism, gastrointestinal dysfunction, renal failure and liver disease, as well as cognitive deficits and behavioural abnormalities. ${ }^{5-7}$

In addition to the direct pathophysiological consequences of abnormal expression patterns of dystrophin isoforms in various tissues, pervasive secondary effects on nonmuscle systems play a key role in the highly complex dystrophic phenotype. As a result of the systematic usage 
of mechanical ventilator support and cardio-protective drug therapy to treat cardio-respiratory insufficiency, the prognosis of Duchenne patients has drastically improved. ${ }^{8}$ Unfortunately the increase in life expectancy is associated with a lengthened period of weakened cardiovascular efficiency, which can negatively affect the appropriate circulation of oxygen, hormones and essential metabolites to peripheral tissues. Importantly, enhanced levels of organ crosstalk between the degenerative musculature and the innate immune system causes sterile inflammation in muscular dystrophy. In contrast to the usually positive effects of immune cell infiltration during muscle repair mechanisms following an acute injury, the chronic inflammatory phenotype of dystrophin-deficient muscle fibres appears to be mostly detrimental. ${ }^{9}$

Dystrophin was previously established to be present in all muscle cell types, ${ }^{10}$ including smooth muscles, ${ }^{11}$ and dystrophinopathies were shown to be associated with gastrointestinal dysfunction. ${ }^{4,5,12-15}$ Thus, to investigate whether the smooth muscle protein constituents of the gastrointestinal system are majorly affected by dystrophin deficiency, we carried out a mass spectrometry-based proteomic analysis of the established genetic $m d x-4 c v$ mouse model of Duchenne muscular dystrophy, which also displays considerable abnormalities in the gastrointestinal system. ${ }^{16,17}$ Since the stomach wall exists in close anatomical connection to the pancreas, we performed the biochemical survey of potential proteome-wide changes using total tissue extracts from the interface between these two essential organs of the gastrointestinal system. Initially the members of the dystrophin-glycoprotein complex were identified in smooth muscle ${ }^{18-20}$, followed by the establishment of smooth muscle and pancreatic marker proteins. The comparative mass spectrometric analysis exposed that the drastic reduction in dystrophin is accompanied by a decrease in other members of the dystrophin-associated complex, as well as structural proteins and the actin-crosslinker filamin. Increases were identified in a variety of mitochondrial components. These findings suggest that the disintegration of cytoskeletal integrity due to the loss of dystrophin and accompanying metabolic disturbances are associated with abnormal gastrointestinal function in $\mathrm{X}$-linked muscular dystrophy.

\section{Materials and Methods}

\section{Materials}

For the proteomic profiling of the interface between the gastrointestinal system and the pancreas in dystrophinopathy, analytical grade reagents and general materials were purchased from Sigma Chemical Company (Dorset, UK), GE Healthcare (Little Chalfont, Buckinghamshire, UK) and Bio-Rad Laboratories (Hemel-Hempstead, Hertfordshire, UK). Extraction buffers were supplemented with a protease inhibitor cocktail from Roche Diagnostics (Mannheim, Germany).
Sequencing grade-modified trypsin and the enzyme LysC, as well as Protease Max Surfactant Trypsin Enhancer, were obtained from Promega (Madison, WI, USA). Protein concentration was determined with the Pierce 660-nm Protein Assay from ThermoFisher Scientific (Dublin, Ireland). For filter-aided sample preparation, Vivacon 500 (Product number: VNOH22) filter units were purchased from Sartorius (Göttingen, Germany).

Ethical approval, animal license and animal maintenance

Male wild type C57/BL6 mice and male $m d x-4 c v$ mice were obtained from the Bioresource Unit of the University of Bonn. ${ }^{21}$ All procedures adhered to German legislation on the use of animals in experimental research (Amt für Umwelt, Verbraucherschutz und Lokale Agenda der Stadt Bonn, North Rhine-Westphalia, Germany). Mice were kept under standard conditions. ${ }^{22}$ For tissue dissection, protein extraction and subsequent proteomic analyses, 12-months old mice were used. Freshly dissected tissue specimens were quick-frozen in liquid nitrogen and transported to Maynooth University in accordance with the Department of Agriculture (animal by-product register number 2016/16 to the Department of Biology, National University of Ireland, Maynooth) on dry ice and stored at $-80^{\circ} \mathrm{C}$ prior to proteomic analysis. ${ }^{23}$

\section{Preparation of mouse tissue extracts for proteomic analysis}

Tissue samples representing the interface between the stomach wall and the pancreas (25 mg weight) from wild type $(\mathrm{n}=8)$ versus dystrophic $m d x-4 c v(\mathrm{n}=8)$ mice were lysed by homogenisation with $200 \mu$ l of lysis solution containing $100 \mathrm{mM}$ Tris-Cl $\mathrm{pH} 7.6,4 \%$ (w/v) sodium dodecyl sulfate and $0.1 \mathrm{M}$ dithiothreitol. Lysis buffer was supplemented with a protease inhibitor cocktail. ${ }^{21}$ The suspension was incubated at $95^{\circ} \mathrm{C}$ for 3 minutes and then sonicated for 30 seconds. ${ }^{24}$ Following centrifugation at $16,000 \mathrm{xg}$ for 5 minutes, tissue extracts were processed for mass spectrometry-based proteomic analysis. ${ }^{22}$ Protein digestion and further processing of the generated peptides was carried out by filter-aided sample preparation (FASP), as recently described in detail. ${ }^{25}$

Label-free liquid chromatography mass spectrometry and proteomic data analysis

Protein identification and comparative proteomics was carried out by an optimized label-free liquid chromatography mass spectrometry procedure. Details of the proteomic workflow describing all preparative steps and analytical procedures using data-dependent acquisition, as well as bioinformatic data handling, were recently outlined in detail. ${ }^{25}$ A Thermo UltiMate 3000 nano system was used for reverse-phased capillary highpressure liquid chromatography and directly coupled inline with a Thermo Orbitrap Fusion Tribrid mass spectrometer (Thermo Fisher Scientific, Waltham, MA, USA). The qualitative data analysis of mass 
Table 1. Proteomic identification of smooth muscle protein markers at the interface between the stomach wall and the pancreas

\begin{tabular}{|l|l|l|l|l|l|}
\hline Accession & \multicolumn{1}{|c|}{ Protein } & Gene & \multicolumn{1}{|c|}{$\begin{array}{c}\text { Coverage } \\
\text { \% }\end{array}$} & Peptides & $\begin{array}{c}\text { Molecular } \\
\text { mass (kDa) }\end{array}$ \\
\hline O08638 & $\begin{array}{l}\text { Myosin heavy chain smMyHC, } \\
\text { Myosin-11, smooth muscle }\end{array}$ & Myh11 & 56 & 132 & 226.9 \\
\hline Q3THE2 & $\begin{array}{l}\text { Myosin regulatory light chain 12B, } \\
\text { smooth muscle }\end{array}$ & Myl12b & 62 & 9 & 19.8 \\
\hline Q6PDN3 & $\begin{array}{l}\text { Myosin light chain kinase, smMLCK, } \\
\text { smooth muscle }\end{array}$ & Mylk & 20 & 35 & 212.8 \\
\hline P62737 & Actin-2, alpha, smooth muscle & Acta2 & 77 & 24 & 42.0 \\
\hline Q921U8 & Smoothelin (Smsmo) & Smtn & 33 & 20 & 100.2 \\
\hline Q99LM3 & Smoothelin-like protein 1 & Smtn11 & 34 & 10 & 49.5 \\
\hline Q8CI12 & Smoothelin-like protein 2 & Smtn12 & 22 & 7 & 49.5 \\
\hline P37804 & $\begin{array}{l}\text { Transgelin (smooth muscle protein } \\
\text { 22-alpha) }\end{array}$ & Tagln & 71 & 16 & 22.6 \\
\hline Q08091 & $\begin{array}{l}\text { Calponin-1 (smooth muscle Calponin } \\
\text { H1) }\end{array}$ & Cnn1 & 60 & 13 & 33.3 \\
\hline Q8BTM8 & Filamin-A & Flna & 62 & 121 & 281.0 \\
\hline Q80X90 & Filamin-B & Flnb & 49 & 90 & 277.7 \\
\hline Q8VHX6 & Filamin-C & Flnc & 59 & 124 & 290.9 \\
\hline A2ASS6 & Titin & Ttn & 56 & 1586 & 3904.1 \\
\hline A2AAJ9 & Obscurin & Obscn & 30 & 146 & 966.0 \\
\hline P26039 & Talin-1 & Tln1 & 44 & 83 & 269.7 \\
\hline Q71LX4 & Talin-2 & Tln2 & 32 & 55 & 253.5 \\
\hline Q9QXS1 & Plectin & Plec & 49 & 213 & 533.9 \\
\hline E9Q557 & Desmoplakin & Dsp & 43 & 119 & 332.7 \\
\hline
\end{tabular}

spectrometric files was carried out with the help of the UniProtKB-SwissProt Mus musculus database with Proteome Discoverer 2.2 using Sequest HT (Thermo Fisher Scientific) and Percolator. ${ }^{24,25}$ For protein identification, the following crucial search parameters were employed: (i) peptide mass tolerance set to $10 \mathrm{ppm}$, (ii) MS/MS mass tolerance set to $0.02 \mathrm{Da}$, (iii) an allowance of up to two missed cleavages, (iv) carbamidomethylation set as a fixed modification and (v) methionine oxidation set as a variable modification. ${ }^{24,25}$ Peptides were filtered using a minimum XCorr score of 1.5 for $1,2.0$ for 2, 2.25 for 3 and 2.5 for 4 charge states, with peptide probability set to high confidence. Quantitative label-free data analysis was performed using Progenesis QI for Proteomics (version 2.0; Nonlinear Dynamics, a Waters company, Newcastle upon Tyne, UK). Peptide and protein identification were achieved with Proteome Discoverer 2.2 using Sequest HT (Thermo Fisher Scientific) and Percolator, and were then imported into Progenesis QI software for further analysis. ${ }^{25}$ Protein identifications were reviewed, and only those which passed the following criteria were considered differentially expressed between experimental groups with high confidence and statistical significance: (i) an ANOVA p-value of $\leq 0.01$ between experimental groups; (ii) proteins with $\geq 2$ unique peptides contributing to the identification. $^{21,24,25}$ To calculate the maximum fold change for a protein, Progenesis QI calculates the mean abundance for that protein in each experimental condition. These mean values are then placed in a condition-vs-condition matrix to find the maximum fold change between any two condition's mean protein abundances. $^{25}$

\section{Results}

Mass spectrometric analysis of the interface between the stomach wall and the pancreas

The proteomic analysis of the interface between the stomach wall and the pancreas, using tissue preparations from 12-months old wild type versus dystrophic $m d x-4 c v$ mice, resulted in the mass spectrometric identification of 5,541 individual protein species. This information on proteins was generated from the combined findings from 16 separate mass spectrometric sample runs. The protein listing of the multi-consensus file was employed to search for protein markers of both smooth muscle cells and pancreatic cells (Tables 1-3). Reliable markers of both organ systems have previously been established by extensive body-wide proteomic surveys as part of the Human Proteome Project ${ }^{26,27}$ and been validated by largescale antibody-based investigations as part of the establishment of the Human Protein Atlas. ${ }^{28}$ The below sections list the identification of tissue markers found in this study. 
Table 2. Proteomic identification of members of the core dystrophin-glycoprotein complex at the interface between the stomach wall and the pancreas

\begin{tabular}{|l|l|l|l|l|l|}
\hline Accession & \multicolumn{1}{|c|}{ Protein } & \multicolumn{1}{|c|}{ Gene } & $\begin{array}{c}\text { Coverage } \\
\text { \% }\end{array}$ & Peptides & $\begin{array}{c}\text { Molecular } \\
\text { mass (kDa) }\end{array}$ \\
\hline P11531 & Dystrophin & Dmd & 33 & 95 & 425.6 \\
\hline Q62165 & Dystroglycan & Dag1 & 15 & 12 & 96.8 \\
\hline P82350 & Alpha-sarcoglycan & Sgca & 35 & 10 & 43.3 \\
\hline P82349 & Beta-sarcoglycan & Sgcb & 42 & 9 & 34.9 \\
\hline P82347 & Delta-sarcoglycan & Sgcd & 23 & 5 & 32.1 \\
\hline P82348 & Gamma-sarcoglycan & Sgcg & 22 & 5 & 32.1 \\
\hline O70258 & Epsilon-sarcoglycan & SGce & 9 & 2 & 49.7 \\
\hline Q9D2N4 & Alpha-dystrobrevin & Dtna & 23 & 11 & 84.0 \\
\hline O70585 & Beta-dystrobrevin & Dtnb & 17 & 6 & 74.4 \\
\hline Q61234 & Alpha-1-syntrophin & Snta1 & 22 & 9 & 53.6 \\
\hline Q99L88 & Beta-1-syntrophin & Sntb1 & 45 & 19 & 58.0 \\
\hline Q61235 & Beta-2-syntrophin & Sntb2 & 25 & 10 & 56.3 \\
\hline
\end{tabular}

Proteomic identification of smooth muscle protein markers

Marker proteins of smooth muscle cells that were identified with a high degree of sequence coverage by unique peptides included major types of contractile components, such as myosin heavy chain isoform smMyHC, myosin regulatory light chain isoform MLC12B, myosin light chain kinase isoform smMLCK and $\alpha-$ actin-2 (Tables 1). Marker proteins were determined by comparison to the data repository of the Human Proteome Map displaying the expressed products of the approximately 20,000 protein-coding genes ${ }^{26,27}$ and the tissue-based map of the proteome in the Human Protein Atlas. ${ }^{28}$ An additional set of excellent protein markers of smooth muscle cells was identified as smoothelin, the smooth muscle protein 22- $\alpha$ transgelin, smooth muscle calponin-1 and filamin-A (Table 1). More general

Table 3. Proteomic identification of pancreatic protein markers at the interface between the stomach wall and the pancreas

\begin{tabular}{|c|c|c|c|c|c|}
\hline Accession & Protein & Gene & $\begin{array}{c}\text { Coverage } \\
\%\end{array}$ & Peptides & $\begin{array}{l}\text { Molecular } \\
\text { mass (kDa) }\end{array}$ \\
\hline P00688 & Pancreatic alpha-amylase & Amy2 & 78 & 34 & 57.3 \\
\hline Q6P8U6 & Pancreatic triacylglycerol lipase & Pnlip & 57 & 20 & 51.4 \\
\hline Q5BKQ4 & Pancreatic lipase-related protein 1 & Pnliprp1 & 72 & 28 & 52.7 \\
\hline P17892 & Pancreatic lipase-related protein 2 & Pnliprp2 & 46 & 20 & 54.0 \\
\hline P00683 & Pancreatic ribonuclease & Rnase1 & 66 & 7 & 16.8 \\
\hline Q9D733 & \begin{tabular}{llr} 
Pancreatic & \multicolumn{2}{c}{ secretory granule } \\
membrane major glycoprotein \\
GP2
\end{tabular} & Gp2 & 37 & 14 & 59.1 \\
\hline Q64285 & Bile salt-activated lipase & Cel & 54 & 25 & 65.8 \\
\hline Q9Z0Y2 & Phospholipase A2 & Pla2g1b & 67 & 7 & 16.3 \\
\hline Q8VCK7 & Syncollin & Sycn & 27 & 4 & 14.6 \\
\hline Q7TPZ8 & Carboxypeptidase A1 & Cpa1 & 88 & 24 & 47.4 \\
\hline Q9CQC2 & Colipase & Clps & 50 & 4 & 12.4 \\
\hline Q9CR35 & Chymotrypsinogen B & Ctrb1 & 77 & 13 & 27.8 \\
\hline Q3SYP2 & Chymotrypsin-C & Ctrc & 26 & 5 & 29.5 \\
\hline Q91X79 & $\begin{array}{l}\text { Chymotrypsin-like elastase family } \\
\text { member } 1\end{array}$ & Cela1 & 79 & 11 & 28.9 \\
\hline P05208 & $\begin{array}{l}\text { Chymotrypsin-like elastase family } \\
\text { member } 2 \mathrm{~A}\end{array}$ & Cela2a & 85 & 12 & 28.9 \\
\hline Q9CQ52 & $\begin{array}{l}\text { Chymotrypsin-like elastase family } \\
\text { member 3B }\end{array}$ & Cela3b & 71 & 12 & 28.9 \\
\hline
\end{tabular}


Table 4. Mass spectrometric identification of proteins with a decreased abundance at the interface between the stomach wall and the pancreas in the mdx-4cv model of Duchenne muscular dystrophy.

\begin{tabular}{|c|c|c|c|c|c|}
\hline Accession & Protein & Gene & Peptides & Anova (p) & $\begin{array}{c}\text { Fold } \\
\text { change }\end{array}$ \\
\hline Q9JMH9 & Unconventional myosin-XVIIIa & Myo18a & 2 & 0.01375 & 44 \\
\hline P97347 & Repetin & Rptn & 2 & 0.042085 & 31.1 \\
\hline Q66K08 & Cartilage intermediate layer protein 1 & Cilp & 2 & 0.028968 & 29.1 \\
\hline Q19LI2 & Alpha-1B-glycoprotein & A1bg & 2 & 0.004887 & 13.5 \\
\hline P11531 & Dystrophin & Dmd & 21 & 0.004186 & 12.2 \\
\hline Q61292 & Laminin subunit beta-2 & Lamb2 & 2 & 0.004332 & 11.1 \\
\hline P82350 & Alpha-sarcoglycan & Sgca & 2 & 0.012255 & 8.8 \\
\hline P03987 & Ig gamma-3 chain $\mathrm{C}$ region & - & 4 & 0.005865 & 7.9 \\
\hline Q9WUB3 & Glycogen phosphorylase, muscle form & Pygm & 3 & 0.007123 & 5.6 \\
\hline P21550 & Beta-enolase & Eno3 & 2 & 0.040089 & 5.2 \\
\hline O55143 & SERCA2 calcium ATPase & Atp2a2 & 2 & 0.00994 & 4.2 \\
\hline A2AAJ9 & Obscurin & Obscn & 4 & 0.02586 & 3.5 \\
\hline P97447 & Four and a half LIM domains protein 1 & Fhl1 & 2 & 0.014399 & 3.4 \\
\hline P13542 & Myosin-8 & Myh8 & 4 & 0.007965 & 3 \\
\hline E9PZQ0 & Ryanodine receptor 1 & Ryr1 & 3 & 0.04258 & 3 \\
\hline A2ASS6 & Titin & Ttn & 32 & 0.027786 & 2.8 \\
\hline P70670 & $\begin{array}{l}\text { Nascent polypeptide-associated complex } \\
\text { subunit alpha, muscle-specific form }\end{array}$ & Naca & 3 & 0.024156 & 2.8 \\
\hline Q921I1 & Serotransferrin & Tf & 2 & 0.010739 & 2.8 \\
\hline Q8BTM8 & Filamin-A & Flna & 2 & 0.004813 & 2.4 \\
\hline P58252 & Elongation factor 2 & Eef2 & 3 & 0.007363 & 2.3 \\
\hline Q60675 & Laminin subunit alpha-2 & Lama2 & 3 & 0.019277 & 2.3 \\
\hline Q9JI91 & Alpha-actinin-2 & Actn2 & 2 & 0.02299 & 2.3 \\
\hline Q5SX40 & Myosin-1 & Myh1 & 8 & 0.023716 & 2.2 \\
\hline Q11011 & Puromycin-sensitive aminopeptidase & Npepps & 4 & 0.012667 & 1.5 \\
\hline Q62165 & Dystroglycan & Dag1 & 2 & 0.012359 & 1.5 \\
\hline Q99KI0 & Aconitate hydratase, mitochondrial & Aco2 & 2 & 0.024421 & 1.5 \\
\hline
\end{tabular}

Listed are proteoforms that were recognized by at least 2 unique peptides.

muscle-associated markers included obscurin, talin, plectin, desmoplakin and the giant protein titin.

Proteomic identification of members of the core dystrophin-glycoprotein complex

All major components of the muscle dystrophinglycoprotein complex, ${ }^{26-28}$ with the exception of the highly hydrophobic and low-molecular-mass protein sarcospan, were identified in smooth muscle cells. Table 2 lists the mass spectrometric identification of dystrophin, dystroglycan, $\alpha$-sarcoglycan, $\beta$-sarcoglycan, $\delta$-sarcoglycan, $\quad \gamma$-sarcoglycan, $\varepsilon$-sarcoglycan, $\alpha$ dystrobrevin, $\beta$-dystrobrevin, $\alpha$-1-syntrophin, $\beta$-1syntrophin and $\beta$-2-syntrophin.
Proteomic identification of pancreatic protein markers

Pancreatic marker proteins that were identified with a high degree of sequence coverage by unique peptides included major types of pancreatic lipases involved in fat digestion, such as pancreatic triacylglycerol lipase PNLIP, bile salt-activated lipase CEL, phospholipase A2/PLA2G1B, colipase CLPS and pancreatic lipaserelated protein PNLIPRP2 of $54 \mathrm{kDa}$ (Table 3), ${ }^{26-28}$ as well as pancreatic lipase-related protein PNLIPRP1 that was previously demonstrated by the human proteome mapping initiative to exhibit the highest protein expression level in pancreas. ${ }^{27}$ Digestive proteinases included carboxypeptidase, chymotrypsin CTRC, 
Table 5, a. Mass spectrometric identification of proteins with an increased abundance at the interface between pancreas and the stomach wall in the mdx-4cv model of Duchenne muscular dystrophy. Listed are proteoforms that were recognized by more than 2 unique peptides.

\begin{tabular}{|c|c|c|c|c|c|}
\hline Accession & Protein & Gene & Peptides & Anova (p) & $\begin{array}{l}\text { Fold } \\
\text { change }\end{array}$ \\
\hline O08601 & $\begin{array}{l}\text { Microsomal triglyceride transfer } \\
\text { protein large subunit }\end{array}$ & Mttp & 4 & 0.046044 & 57.9 \\
\hline P35441 & Thrombospondin-1 & Thbs1 & 7 & 0.002387 & 10.7 \\
\hline P01878 & Ig alpha chain $\mathrm{C}$ region & - & 4 & 0.009506 & 9 \\
\hline Q9WUR9 & Adenylate kinase 4, mitochondrial & Ak4 & 3 & 0.015851 & 8.5 \\
\hline P47738 & $\begin{array}{l}\text { Aldehyde dehydrogenase, } \\
\text { mitochondrial }\end{array}$ & Aldh2 & 3 & 0.02759 & 8.4 \\
\hline Q9WU79 & $\begin{array}{l}\text { Proline dehydrogenase } 1 \text {, } \\
\text { mitochondrial }\end{array}$ & Prodh & 3 & 0.028809 & 7.4 \\
\hline P15105 & Glutamine synthetase & Glul & 3 & 0.035918 & 6.9 \\
\hline Q8C196 & $\begin{array}{l}\text { Carbamoyl-phosphate synthase, } \\
\text { mitochondrial }\end{array}$ & Cps1 & 3 & 0.048286 & 5.3 \\
\hline Q9QYF1 & Retinol dehydrogenase 11 & Rdh11 & 3 & 0.009304 & 4.8 \\
\hline O35381 & $\begin{array}{l}\text { Acidic leucine-rich nuclear } \\
\text { phosphoprotein } 32 \text { family member A }\end{array}$ & Anp32a & 3 & 0.000147 & 4.6 \\
\hline P97742 & Carnitine O-palmitoyl-transferase 1 & Cpt1a & 6 & 0.007153 & 4.3 \\
\hline P16675 & Lysosomal protective protein & Ctsa & 3 & 0.017105 & 4.1 \\
\hline Q8K1B8 & Fermitin 3 & Fermt3 & 3 & 0.003082 & 3.6 \\
\hline Q05920 & Pyruvate carboxylase, mitochondrial & Pc & 3 & 0.021666 & 3.4 \\
\hline Q99LP6 & GrpE protein 1, mitochondrial & Grpel1 & 3 & 0.00354 & 3.3 \\
\hline E9Q4Z2 & Acetyl-CoA carboxylase 2 & Acacb & 3 & 0.022647 & 3.2 \\
\hline P51855 & Glutathione synthetase & Gss & 3 & 0.008555 & 3 \\
\hline Q8CC88 & $\begin{array}{l}\text { von Willebrand factor A domain- } \\
\text { containing protein } 8\end{array}$ & Vwa8 & 9 & 0.002283 & 2.8 \\
\hline Q9JII6 & $\begin{array}{l}\text { Aldo-keto reductase family } 1 \text { member } \\
\text { A1 }\end{array}$ & Akr1a1 & 4 & 0.017949 & 2.8 \\
\hline Q8CGK3 & Lon protease, mitochondrial & Lonp1 & 7 & 0.000701 & 2.7 \\
\hline P01942 & Hemoglobin subunit alpha & Hba & 3 & 0.000471 & 2.5 \\
\hline Q9JLJ2 & $\begin{array}{l}\text { 4-trimethylamino-butyraldehyde } \\
\text { dehydrogenase }\end{array}$ & Aldh9a1 & 3 & 0.035947 & 2.5 \\
\hline P29351 & $\begin{array}{l}\text { Tyrosine-protein phosphatase non- } \\
\text { receptor type } 6\end{array}$ & Ptpn6 & 4 & 0.023282 & 2.4 \\
\hline
\end{tabular}

chymotrypsin-like elastases CELA1, CELA2A and CELA3B. In addition, highly enriched pancreatic markers were identified as pancreatic $\alpha$-amylase AMY2, syncollin, pancreatic ribonuclease RNase1 and pancreatic secretory granule membrane major glycoprotein GP2 (Table 3). ${ }^{26-28}$

Proteins with a decreased abundance at the interface between the stomach wall and the pancreas in the $m d x$ $4 c v$ model of dystrophinopathy

The most reduced protein species in the tissue specimens under investigation were identified as myosin-XVIIIa, repetin, cartilage intermediate layer protein 1 and $\alpha-1 \mathrm{~B}$ glycoprotein (Table 4). Of note, the expression levels of core members of the dystrophin-glycoprotein complex including dystrophin, laminin, $\alpha$-sarcoglycan and dystroglycan, were confirmed to be decreased in the dystrophic phenotype. Additional protein species with a reduced concentration were identified as the smooth muscle marker filamin-A and the cytoskeletal proteins obscurin and titin.

Proteins with an increased abundance at the interface between the stomach wall and the pancreas in the $m d x$ $4 \mathrm{cv}$ model of dystrophinopathy

A large number of diverse proteins was identified with elevated expression levels in the $m d x-4 c v$ mouse preparation (Table 5, a, b). The most increased protein 
Table 5, b. Mass spectrometric identification of proteins with an increased abundance at the interface between pancreas and the stomach wall in the $m d x-4 c v$ model of Duchenne muscular dystrophy. Listed are proteoforms that were recognized by more than 2 unique peptides.

\begin{tabular}{|c|c|c|c|c|c|}
\hline Q61233 & Plastin-2 & Lcp1 & 3 & 0.015693 & 2.4 \\
\hline Q9JLZ3 & $\begin{array}{l}\text { Methylglutaconyl-CoA hydratase, } \\
\text { mitochondrial }\end{array}$ & Auh & 3 & 0.04646 & 2.3 \\
\hline P26039 & Talin-1 & $\mathrm{T} \ln 1$ & 3 & 0.00156 & 2.3 \\
\hline Q9CZN7 & $\begin{array}{l}\text { Serine hydroxymethyl-transferase, } \\
\text { mitochondrial }\end{array}$ & Shmt2 & 3 & 0.021521 & 2.3 \\
\hline P30999 & Catenin delta-1 & Ctnnd1 & 5 & 0.024074 & 2.2 \\
\hline O89053 & Coronin-1A & Coro1a & 3 & 0.01593 & 2.2 \\
\hline P50171 & Estradiol 17-beta-dehydrogenase 8 & Hsd17b8 & 3 & 0.012644 & 2.2 \\
\hline P52825 & $\begin{array}{l}\text { Carnitine O-palmitoyl-transferase 2, } \\
\text { mitochondrial }\end{array}$ & Cpt2 & 6 & 0.013181 & 2.1 \\
\hline P63038 & $\begin{array}{l}60 \text { kDa heat shock protein, } \\
\text { mitochondrial }\end{array}$ & Hspd1 & 5 & 0.007267 & 2.1 \\
\hline Q8BGQ7 & Alanine--tRNA ligase, cytoplasmic & Aars & 3 & 0.007629 & 2.1 \\
\hline P38647 & Stress-70 protein, mitochondrial & Hspa9 & 7 & 0.000879 & 2 \\
\hline P56480 & $\begin{array}{l}\text { ATP synthase subunit beta, } \\
\text { mitochondrial }\end{array}$ & Atp5f1b & 3 & 0.02928 & 2 \\
\hline P02088 & Hemoglobin subunit beta-1 & Hbb-b1 & 5 & 0.008807 & 1.9 \\
\hline Q8VDD5 & Myosin-9 & Myh9 & 18 & 0.006118 & 1.8 \\
\hline P26231 & Catenin alpha-1 & Ctnna1 & 3 & 0.0094 & 1.8 \\
\hline Q02819 & Nucleobindin-1 & Nucb1 & 5 & 0.002401 & 1.7 \\
\hline P11983 & T-complex protein 1 subunit alpha & Tcp1 & 4 & 0.000647 & 1.7 \\
\hline Q8QZT1 & $\begin{array}{l}\text { Acetyl-CoA acetyltransferase, } \\
\text { mitochondrial }\end{array}$ & Acat1 & 3 & 0.030345 & 1.7 \\
\hline P80313 & T-complex protein 1 subunit eta & Cct7 & 3 & 0.002462 & 1.7 \\
\hline Q68FD5 & Clathrin heavy chain 1 & Cltc & 4 & 0.004151 & 1.6 \\
\hline P61979 & $\begin{array}{l}\text { Heterogeneous nuclear } \\
\text { ribonucleoprotein K }\end{array}$ & Hnrnpk & 3 & 0.006035 & 1.6 \\
\hline Q3U0V1 & Far upstream element-binding protein 2 & Khsrp & 3 & 0.017072 & 1.6 \\
\hline Q9D0E1 & $\begin{array}{l}\text { Heterogeneous nuclear } \\
\text { ribonucleoprotein } \mathrm{M}\end{array}$ & Hnrnpm & 3 & 0.006943 & 1.6 \\
\hline O35643 & AP-1 complex subunit beta-1 & Ap1b1 & 5 & 0.013862 & 1.5 \\
\hline Q9DBG3 & AP-2 complex subunit beta & Ap2b1 & 4 & 0.004566 & 1.5 \\
\hline P40142 & Transketolase & Tkt & 3 & 0.013685 & 1.5 \\
\hline Q93092 & Transaldolase & Taldo1 & 3 & 0.004619 & 1.5 \\
\hline
\end{tabular}

species in the tissue specimen under investigation were shown to be the microsomal triglyceride transfer protein and thrombospondin. Interestingly, the expression of a large number of mitochondrial proteins was found to be significantly increased. This included the mitochondrial isoforms of adenylate kinase, aldehyde dehydrogenase, proline dehydrogenase, carbamoyl-phosphate synthase, pyruvate carboxylase, GrpE protein, lon protease, methylglutaconyl-CoA hydratase, serine hydroxymethyl-transferase, carnitine O-palmitoyl- transferase, $60 \mathrm{kDa}$ heat shock protein, stress-70 protein, ATP synthase and acetyl-CoA acetyltransferase (Tables 5, a, b).

\section{Discussion}

Duchenne muscular dystrophy is a highly progressive neuromuscular disorder that initially affects the skeletal musculature, which is characterized by fibre degeneration, reactive myofibrosis and sterile inflammation. ${ }^{2,9}$ Besides late-onset cardio-respiratory 
insufficiency, ${ }^{4}$ many other organ systems are impaired in Duchenne patients, ${ }^{5-7}$ including the gastrointestinal tract. $^{12-15}$ In analogy to Duchenne patients, dystrophic $m d x$-type animal models of X-linked muscular dystrophy, which were used in this investigation in the form of the $m d x-4 c v$ mouse, also exhibit impairments of the gastrointestinal system. ${ }^{16,17}$ This report describes the characterization of a crucial tissue junction within the gastrointestinal system using mass spectrometry. The proteomic profiling of the interface between the stomach wall with its extensive layers of smooth muscle cells and the pancreas with its key exocrine function in digestion revealed interesting changes in various protein families in dystrophinopathy.

Importantly, the large-scale proteomic analysis of the tissue preparation under investigation clearly identified typical protein markers that are enriched in smooth muscles of the gastrointestinal tract, ${ }^{26-28}$ including smooth muscle myosin heavy chain (smMyHC, myosin11), smooth muscle myosin light chain (MLC-12B), smooth muscle myosin light chain kinase (smMLCK) and smooth muscle actin ( $\alpha$-actin-2), as well as the cytoskeletal smooth muscle protein smoothelin, the $\mathrm{Ca}^{2+}$ binding protein calponin-1 and the actin-crosslinking protein filamin-A. In relation to pancreatic protein markers, a large number of key pancreas components were identified by mass spectrometry with a considerable coverage of their peptide sequences. The pancreas acts as a heterocrine gland with exocrine functions based on the secretion of digestive enzymes to the gastrointestinal tract and endocrine functions that involve the release of essential hormones. Distinct pancreatic markers were detected in tissue extracts from the tissue preparation including pancreatic $\alpha$-amylase and the pancreatic acinar cell protein syncollin, as well as the pancreatic lipases PNLIP, PNLIPRP1, PNLIPRP2, CEL and PLA2G1B. ${ }^{26-}$ ${ }^{28}$ This established the presence of both the stomach wall with its extensive smooth muscle layers and the anatomically connected pancreatic cells in this mouse tissue preparation.

The detailed proteomic analysis of the interface between the stomach wall and the pancreas confirmed previous biochemical and cell biological studies that have shown the presence of both dystrophin ${ }^{10,11}$ and dystrophinassociated proteins ${ }^{18-20}$ in smooth muscle cells. Dystrophin exists in various tissue-specific isoforms with the largest proteoforms of apparent $427 \mathrm{kDa}$ being mostly expressed in muscle cells and the nervous system. ${ }^{10}$ In skeletal muscles, the dystrophin isoform Dp427-M is tightly linked to the integral glycoprotein $\beta$-dystroglycan which in turn binds via $\alpha$-dystroglycan to laminin-211 and the wider collagen network of the extracellular matrix. Since full-length dystrophin acts as an actinbinding protein through its amino-terminal and rod domains, this interaction provides a strengthening transsarcolemmal linkage between the intracellular cytoskeleton and the extracellular basal lamina. Other members of the core dystrophin complex are represented by the integral sarcoglycans and the cytosolic components dystrobrevin and syntrophin. The mass spectrometric findings presented here clearly identified the main members of the dystrophin-glycoprotein complex in the stomach wall/pancreas tissue preparation, including dystrophin, $\alpha / \beta$-dystroglycan, $\alpha / \beta / \delta / \gamma / \varepsilon-$ sarcoglycan, $\alpha / \beta$-dystrobrevin, $\alpha 1 / \beta 1 / \beta 2$-syntrophin and laminin.

The comparison of wild type versus $m d x-4 c v$ tissue preparations demonstrated a drastic reduction in dystrophin and concomitant reduction in sarcoglycan, dystroglycan and laminin. Thus, in analogy to both skeletal muscles and the heart, the dystrophinglycoprotein complex appears to be also majorly affected in smooth muscles of the stomach wall. Of note, the expression of the smooth muscle marker filamin-A, in addition to obscurin and titin, was also found to be decreased in the $m d x-4 c v$ phenotype. This suggests that the collapse of the cytoskeletal support system may weaken contractile smooth muscle function and thereby facilitate gastrointestinal dysfunction in dystrophinoapthy. ${ }^{12-17}$ Reduction in myosin isoform XVIIIa, repetin, the cartilage intermediate layer protein, serotransferrin, the ryanodine receptor and the $\mathrm{Ca}^{2+}$ ATPase agree with the pathophysiological concept of changes in cytoskeletal maintenance, extracellular matrix organisation, cartilage scaffolding and $\mathrm{Ca}^{2+}$-cycling through the sarcoplasmic reticulum, respectively.

The drastic increase of the large subunit of microsomal triglyceride transfer protein is probably due to alterations in the $m d x-4 c v$ pancreas, since this protein facilitates the transport of fat molecules between phospholipid surfaces. Previous proteomic surveys revealed decreased pancreatic marker proteins in biofluids, including reduced levels of chymotrypsin-like elastase family member $2 \mathrm{~A}$ in $m d x-4 c v$ serum ${ }^{23}$ and pancreatic alphaamylase in $m d x-4 c v$ urine, ${ }^{22}$ indicating decreased secretion of these enzymes into circulation. However, no altered abundance of these pancreatic proteins was observed in this report. Higher levels of the adhesive glycoprotein named thrombospondin-1, a protein that is highly expressed in both muscle and pancreas, indicates potential adaptations in the mediation of cell-to-cell-tomatrix interactions due to dystrophin deficiency. Increased protein levels in the $m d x-4 c v$ preparation including a large number of mitochondrial proteins, such as enzymes involved in oxidative phosphorylation (ATP synthase), nucleotide homeostasis (adenylate kinase), alcohol metabolism (aldehyde dehydrogenase), amino acid degradation (proline dehydrogenase), ammonia removal (carbamoyl-phosphate synthase), pyruvate conversion (pyruvate carboxylase), detoxification (methylglutaconyl-CoA hydratase), purine biosynthesis (serine hydroxymethyl-transferase), fatty acid oxidation (carnitine O-palmitoyl-transferase, acetyl-CoA acetyltransferase) and the cellular stress response $(60 \mathrm{kDa}$ heat shock protein, lon protesae, stress-70 protein, GrpE protein). ${ }^{26-28}$ This could relate to a shift in metabolic 
processes due to dystrophin deficiency. Disturbed energy metabolism has also been observed in the diaphragm, ${ }^{21}$ liver $^{29}$ and kidney ${ }^{30}$ of the $m d x-4 c v$ mouse model of $\mathrm{X}$ linked muscular dystrophy. Loss of dystrophin appears to cause severe primary and secondary abnormalities in a variety of tissue systems and organ crosstalk seems to play a major role in the cellular pathogenesis of dystrophinopathy. ${ }^{24}$

\section{Conclusions}

The proteomic profiling of the interface between the stomach wall and the pancreas in the $m d x-4 c v$ model of dystrophinopathy has confirmed the multi-systemic character of the dystrophic phenotype. The systematic and large-scale survey of this tissue preparation by mass spectrometry revealed the presence of the core members of the dystrophin-glycoprotein complex in the gastrointestinal tract.

Comparative proteomics identified a reduced concentration of dystrophin and its associated proteins sarcoglycan and dystroglycan, as well as laminin, obscurin, titin and filamin.

This agrees with the pathophysiological concept of a loss of cytoskeletal and plasmalemmal integrity in smooth muscle cells. A change in mitochondrial proteins suggests that metabolic disturbances and/or adaptations play a role in abnormal gastrointestinal function. The newly described proteomic changes can now be used to establish novel biomarker candidates for studying the gastrointestinal system in X-linked muscular dystrophy and potentially improve differential diagnosis, prognosis and therapy monitoring.

\section{Authors contributions}

$\mathrm{PD}$, DS, and KO were involved in the conceptualization and initiation of this project, as well as the design of the research strategy. SG and PD performed the biochemical experiments and analysed the data. MZ and HS were involved in the preparation of tissue samples. $\mathrm{MH}$ and PM performed the mass spectrometric and bioinformatic analysis. All authors were involved in the writing and final editing of the manuscript.

\section{Acknowledgments}

The authors thank Drs. Stephan Baader and Jens Reimann, University of Bonn, for their support of this project

\section{Funding}

This work was supported by the Kathleen Lonsdale Institute for Human Health Research at Maynooth University. The Orbitrap Fusion Tribrid mass spectrometer was funded under a Science Foundation Ireland Infrastructure Award to Dublin City University (SFI 16/RI/3701).

\section{Conflict of Interest}

The authors declare no conflicts of interests

\section{Ethical Publication Statement}

We confirm that we have read the Journal's position on issues involved in ethical publication and affirm that this report is consistent with those guidelines.

\section{Corresponding Author}

Kay Ohlendieck, Department of Biology, Maynooth University, National University of Ireland, Maynooth W23F2H6, Co. Kildare, Ireland - Phone: 353-1-7083842 ORCID iD: 0000-0002-6266-4510

Email: kay.ohlendieck@mu.ie

\section{E-mail and ORCiD of co-authors}

Paul Dowling: paul.dowling@mu.ie

ORCID iD: 0000-0002-9290-9267

Stephen Gargan: stephen.gargan@mu.ie

ORCID iD: 0000-0003-1005-8372

Margit Zweyer: margit.zweyer@dzne.de

ORCID iD: 0000-0001-5615-1869

Hemmen Sabir: hemmen.sabir@dzne.de

ORCID iD: None

Michael Henry: Michael.henry@dcu.ie

ORCID iD: 0000-0001-5312-4961

Paula Meleady: paula.meleady@dcu.ie

ORCID iD: 0000-0001-5306-310X

Dieter Swandulla: swandulla@uni-bonn.de

ORCID iD: 0000-0003-0923-7090

\section{References}

1. Mercuri E, Bönnemann CG, Muntoni F. Muscular dystrophies. Lancet. 2019;394(10213):2025-2038. doi: 10.1016/S0140-6736(19)32910-1.

2. Guiraud S, Aartsma-Rus A, Vieira NM, Davies KE, van Ommen GJ, Kunkel LM. The Pathogenesis and Therapy of Muscular Dystrophies. Annu Rev Genomics Hum Genet. 2015;16:281-308. doi: 10.1146/annurev-genom-090314-025003. Epub 2015 Jun 4.

3. Bladen CL, Salgado D, Monges S, Foncuberta ME, Kekou K, Kosma K, Dawkins H, Lamont L, Roy AJ, Chamova T, Guergueltcheva V, Chan S, Korngut L, Campbell C, Dai Y, Wang J, Barišić N, Brabec P, Lahdetie J, Walter MC, Schreiber-Katz O, Karcagi V, Garami M, Viswanathan V, Bayat F, Buccella F, Kimura E, Koeks Z, van den Bergen JC, Rodrigues M, Roxburgh R, Lusakowska A, Kostera-Pruszczyk A, Zimowski J, Santos R, Neagu E, Artemieva S, Rasic VM, Vojinovic D, Posada M, Bloetzer C, Jeannet PY, Joncourt F, Díaz-Manera J, Gallardo E, Karaduman AA, Topaloğlu H, El Sherif R, Stringer A, Shatillo AV, Martin AS, Peay HL, Bellgard MI, Kirschner J, Flanigan KM, Straub V, Bushby K, Verschuuren J, Aartsma-Rus A, Béroud C, Lochmüller $H$. The TREAT-NMD DMD Global Database: analysis of more than 7,000 Duchenne muscular dystrophy mutations. Hum Mutat. 2015 Apr;36(4):395-402. doi: 10.1002/humu.22758. Epub 2015 Mar 17. 
4. Goemans N, Buyse G. Current treatment and management of dystrophinopathies. Curr Treat Options Neurol. 2014 May;16(5):287. doi: 10.1007/ s11940-014-0287-4.

5. Birnkrant DJ, Bushby K, Bann CM, Apkon SD, Blackwell A, Brumbaugh D, Case LE, Clemens PR, Hadjiyannakis S, Pandya S, Street N, Tomezsko J, Wagner KR, Ward LM, Weber DR; DMD Care Considerations Working Group. Diagnosis and management of Duchenne muscular dystrophy, part 1: diagnosis, and neuromuscular, rehabilitation, endocrine, and gastrointestinal and nutritional management. Lancet Neurol. 2018;17(3):251-267. doi: 10.1016/S1474-4422(18)30024-3. Epub 2018 Feb 3.

6. Birnkrant DJ, Bushby K, Bann CM, Alman BA, Apkon SD, Blackwell A, Case LE, Cripe L, Hadjiyannakis S, Olson AK, Sheehan DW, Bolen J, Weber DR, Ward LM; DMD Care Considerations Working Group. Diagnosis and management of Duchenne muscular dystrophy, part 2: respiratory, cardiac, bone health, and orthopaedic management. Lancet Neurol. 2018 Apr;17(4):347-361. doi: 10. 1016/S1474-4422(18)30025-5. Epub 2018 Feb 3.

7. Birnkrant DJ, Bushby K, Bann CM, Apkon SD, Blackwell A, Colvin MK, Cripe L, Herron AR, Kennedy A, Kinnett K, Naprawa J, Noritz G, Poysky J, Street N, Trout CJ, Weber DR, Ward LM; DMD Care Considerations Working Group. Diagnosis and management of Duchenne muscular dystrophy, part 3: primary care, emergency management, psychosocial care, and transitions of care across the lifespan. Lancet Neurol. 2018 May;17(5):445-455. doi: 10.1016/S1474-4422(18) 30026-7. Epub 2018 Feb 2.

8. Messina S, Vita GL. Clinical management of Duchenne muscular dystrophy: the state of the art. Neurol Sci. 2018 Nov;39(11):1837-1845. doi: 10.1007/s10072-018-3555-3. Epub 2018 Sep 14.

9. Tidball JG, Welc SS, Wehling-Henricks M. Immunobiology of Inherited Muscular Dystrophies. Compr Physiol. 2018 Sep 14;8(4):1313-1356. doi: 10.1002/cphy.c170052.

10. Hoffman EP, Hudecki MS, Rosenberg PA, Pollina CM, Kunkel LM. Cell and fiber-type distribution of dystrophin. Neuron. 1988 Jul;1(5):411-20. doi: 10.1016/0896-6273(88)90191-2.

11. Lionarons JM, Hoogland G, Hendriksen RGF, Faber CG, Hellebrekers DMJ, Van Koeveringe GA, Schipper S, Vles JSH. Dystrophin is expressed in smooth muscle and afferent nerve fibers in the rat urinary bladder. Muscle Nerve. 2019 Aug;60(2): 202210. doi: 10.1002/mus.26518. Epub 2019 Jun 7.

12. Barohn RJ, Levine EJ, Olson JO, Mendell JR. Gastric hypomotility in Duchenne's muscular dystrophy. N Engl J Med. 1988 Jul 7;319(1):15-8. doi: 10.1056/NEJM198807073190103.
13. Jaffe KM, McDonald CM, Ingman E, Haas J. Symptoms of upper gastrointestinal dysfunction in Duchenne muscular dystrophy: case-control study. Arch Phys Med Rehabil. 1990 Sep;71(10):742-4.

14. Borrelli O, Salvia G, Mancini V, Santoro L, Tagliente F, Romeo EF, Cucchiara S. Evolution of gastric electrical features and gastric emptying in children with Duchenne and Becker muscular dystrophy. Am J Gastroenterol. 2005 Mar;100(3):695-702. doi: 10.1111/j.1572-0241. 2005.41303.x.

15. Lo Cascio CM, Goetze O, Latshang TD, Bluemel S, Frauenfelder T, Bloch KE. Gastrointestinal Dysfunction in Patients with Duchenne Muscular Dystrophy. PLoS One. 2016 Oct 13;11(10):e01 63779.doi: 10.1371/journal.pone.0163779. eCol lection 2016.

16. Mulè F, Amato A, Serio R. Gastric emptying, small intestinal transit and fecal output in dystrophic (mdx) mice. J Physiol Sci. 2010 Jan;60(1):75-9. doi: 10.1007/s12576-009-0060-8.

17. Singh K, Randhwa G, Salloum FN, Grider JR, Murthy KS. Decreased smooth muscle function, peristaltic activity, and gastrointestinal transit in dystrophic (mdx) mice. Neurogastroenterol Motil. 2020 Aug 12;e13968. doi: 10.1111/nmo.13968. Online ahead of print.

18. Halayko AJ, Stelmack GL. The association of caveolae, actin, and the dystrophin-glycoprotein complex: a role in smooth muscle phenotype and function? Can J Physiol Pharmacol. 2005 Oct;83(10):877-91. doi: 10.1139/y05-107.

19. Sharma P, Ghavami S, Stelmack GL, McNeill KD, Mutawe MM, Klonisch T, Unruh H, Halayko AJ. beta-Dystroglycan binds caveolin-1 in smooth muscle: a functional role in caveolae distribution and $\mathrm{Ca}^{2+}$ release. J Cell Sci. 2010 Sep 15;123(Pt 18):3061-70. doi: 10.1242/jcs.066712. Epub 2010 Aug 24.

20. Sharma P, Jha A, Stelmack GL, Detillieux K, Basu S, Klonisch T, Unruh H, Halayko AJ. Characterization of the dystrophin-glycoprotein complex in airway smooth muscle: role of delta-sarcoglycan in airway responsiveness. Can J Physiol Pharmacol. 2015;93(3):195-202.

21. Murphy S, Zweyer M, Raucamp M, Henry M, Meleady P, Swandulla D, Ohlendieck K. Proteomic profiling of the mouse diaphragm and refined mass spectrometric analysis of the dystrophic phenotype. J Muscle Res Cell Motil. 2019 Mar;40(1):9-28. doi: 10.1007/s10974-019-09507-z. Epub 2019 Mar 19.

22. Gargan S, Dowling P, Zweyer M, Swandulla D, Ohlendieck K. Identification of marker proteins of muscular dystrophy in the urine proteome from the mdx-4cv model of dystrophinopathy. Mol Omics. 2020 Jun 1;16(3):268-278. doi: 10.1039/c9mo00 182d. Epub 2020 Mar 25.

23. Murphy S, Dowling P, Zweyer M, Henry M, Meleady $\mathrm{P}$, Mundegar RR, Swandulla D, Ohlendieck K. 
Proteomic profiling of mdx-4cv serum reveals highly elevated levels of the inflammation-induced plasma marker haptoglobin in muscular dystrophy. Int J Mol Med. 2017;39(6):1357-1370.

24. Dowling P, Gargan S, Zweyer M, Henry M, Meleady P, Swandulla D, Ohlendieck K. Proteome-wide Changes in the mdx-4cv Spleen due to Pathophysiological Cross Talk with DystrophinDeficient Skeletal Muscle. iScience. 2020 Aug 26;23(9):101500. doi: 10.1016/j.isci.2020.101500. Online ahead of print.

25. Dowling P, Gargan S, Zweyer M, Henry M, Meleady P, Swandulla D, Ohlendieck K. Protocol for the Bottom-Up Proteomic Analysis of Mouse Spleen. STAR Protocol. 2020 Dec 3;1(3):100196. doi: 10. 1016/j.xpro.2020.100196. eCollection 2020 Dec 18.

26. Wilhelm M, Schlegl J, Hahne H, Gholami AM, Lieberenz M, Savitski MM, Ziegler E, Butzmann L, Gessulat S, Marx H, Mathieson T, Lemeer S, Schnatbaum K, Reimer U, Wenschuh H, Mollenhauer M, Slotta-Huspenina J, Boese JH, Bantscheff M, Gerstmair A, Faerber F, Kuster B. Massspectrometry-based draft of the human proteome. Nature. 2014 May 29;509(7502):582-7. doi: 10.1038/nature13319.

27. Kim MS, Pinto SM, Getnet D, Nirujogi RS, Manda SS, Chaerkady R, Madugundu AK, Kelkar DS, Isserlin R, Jain S, Thomas JK, Muthusamy B, LealRojas P, Kumar P, Sahasrabuddhe NA, Balakrishnan L, Advani J, George B, Renuse S, Selvan LD, Patil AH, Nanjappa V, Radhakrishnan A, Prasad S, Subbannayya T, Raju R, Kumar M, Sreenivasamurthy SK, Marimuthu A, Sathe GJ, Chavan S, Datta KK, Subbannayya Y, Sahu A, Yelamanchi SD, Jayaram S, Rajagopalan P, Sharma J, Murthy KR, Syed N, Goel R, Khan AA, Ahmad S, Dey G, Mudgal K, Chatterjee A, Huang TC, Zhong J,
Wu X, Shaw PG, Freed D, Zahari MS, Mukherjee KK, Shankar S, Mahadevan A, Lam H, Mitchell CJ, Shankar SK, Satishchandra P, Schroeder JT, Sirdeshmukh R, Maitra A, Leach SD, Drake CG, Halushka MK, Prasad TS, Hruban RH, Kerr CL, Bader GD, Iacobuzio-Donahue CA, Gowda H, Pandey A. A draft map of the human proteome. Nature. 2014 May 29;509(7502):575-81. doi: 10.1038/nature13302.

28. Uhlén M, Fagerberg L, Hallström BM, Lindskog C, Oksvold P, Mardinoglu A, Sivertsson Å, Kampf C, Sjöstedt E, Asplund A, Olsson I, Edlund K, Lundberg E, Navani S, Szigyarto CA, Odeberg J, Djureinovic D, Takanen JO, Hober S, Alm T, Edqvist PH, Berling $\mathrm{H}$, Tegel H, Mulder J, Rockberg J, Nilsson P, Schwenk JM, Hamsten M, von Feilitzen K, Forsberg M, Persson L, Johansson F, Zwahlen M, von Heijne G, Nielsen J, Pontén F. Proteomics. Tissue-based map of the human proteome. Science. 2015 Jan 23;347(6220): 1260419. doi: 10.1126/science.1260 419.

29. Murphy S, Zweyer M, Henry M, Meleady P, Mundegar RR, Swandulla D, Ohlendieck K. Proteomic profiling of liver tissue from the mdx-4cv mouse model of Duchenne muscular dystrophy. Clin Proteomics. 2018 Oct 29;15:34. doi: 10.1186/s12014018-9212-2. eCollection 2018.

30. Dowling P, Zweyer M, Raucamp M, Henry M, Meleady P, Swandulla D, Ohlendieck K. Proteomic and cell biological profiling of the renal phenotype of the mdx-4cv mouse model of Duchenne muscular dystrophy. Eur J Cell Biol. 2020;99(1):151059. doi: 10.1016/j.ejcb.2019.1510 59. Epub 2019 Nov 18.

Submission: January 20, 2021 Accepted for publication: March 2, 2021 